\title{
AUSTRIAN CONSTITUTION - GENERAL ASPECTS
}

DOI: $10.47743 /$ rdc-2018-1-0004

Olga-Andreea URDA ${ }^{1}$

\section{Abstract}

The present article aims at presenting the Austrian fundamental law with the highlighting of some essential aspects regarding the exercise of the legislative, executive and judicial powers, the institutional particularities and, last but not least, the evolution of the regulation that was generated generated by the state's accession to the European Union. Constitutional control is another aspect that we have focused into the study, considering the important role of the Constitutional Court in the rule of law.

The conducted analysis has significant valences, especially in the context in which it can signify a point of reference in the comparative study of constitutional regulations.

Keywords: legislative power; federal president; constitutional control; separation of powers in the state; human rights; subsidiarity principle

\section{Introductory aspects}

Following the collapse of the Habsburg Empire after the First World War, on $12^{\text {th }}$ December 1918 the Republic of Austria is proclaimed a federal state ${ }^{2}$. The Austrian Constitution was adopted in 1920 and re-consolidated in 1929 and has in the largest proportion the footprint of the great Austrian theorist of the rule of law, Hans Kelsen, also being Austria's first constitution after the fall of the Austro-Hungarian Empire ${ }^{3}$.

The Second World War, the establishment of the Nazi dictatorship and the annexation of Austria by Germany, led to the suspension of the application of the 1929

\footnotetext{
${ }^{1}$ Univ. lecturer, PhD, Faculty of Law, "Alexandru Ioan Cuza" University of Iasi, lawyer at Iasi Bar, e-mail: olga.alexandru@uaic.ro.

${ }^{2}$ C. Călinoiu, V. Duculescu, G. Duculescu, Comparative constitutional law, $4^{\text {th }}$ edition, updated and revised, Ist volume, Lumina Lex Publisher house, Bucharest, 2007, p. 313.

${ }^{3}$ See: S. Lagi, Hans Kelsen and the Austrian Constitutional Court (1918-1929), in Co-herencia Journal,Vol. 9, No 16 Enero-Junio 2012, Medellín, Colombia (ISSN 1794-5887), pp. 273-295; V. Țăndăreanu, S. Popescu, The European Union and national constitutional reviews, in the Legislative Information Bulletin, nr. 4/2003, pp. 3-13; I. Guceac, Constitutions of the World States, Cartier Publisher house, Kishinev, 2016, p. 53.
} 
Austrian basic law for the period 1934-19454. The Declaration of Independence of 27 April 1945 reinstated the Austrian state, thus from May 1945 the 1920 Constitution was again producing its effects. The Treaty of Reconstruction of an Independent and Democratic Austria was signed in Vienna on May 15, 1955 and had as its main objective the re-establishment of Austria as a sovereign and independent state.

With the commencement of Austria's accession to the European Union, 23 amendments were made to the Constitution (1983-1995) to adequately regulate the relationship between the Austrian state and the European Union. The changes mainly concern the manner in which the various state bodies participate in the decision-making process of the Union. Significant changes to the Constitution took place in 2009, 2013, 2014 and 2016.

The Austrian Basic Law is structured in eight chapters: General Provisions European Union (art. 1-23k); Legislation of the Federation (art. 24-59b); Federal Execution (art. 60-94); Legislation and Execution by the Länder (art. 95-120c); Control of Accounts and Financial Management (art. 121-128); Constitutional and Administrative Guarantees (art. 129-148); The Office of the People's Attorney (Volksanwaltschaft) (art. 148a-148j); Final Provisions (art. 149-152).

Austria is a federal state formed of nine autonomous counties: Burgenland, Carinthia, Lower Austria, Upper Austria, Salzburg, Styria, Tyrol, Vorarlberg and Vienna.

\section{Head of State - Federal President}

The Federal President is elected by the population of the Federation on the basis of the equal, direct, personal, free and secret vote of men and women who have the right to vote for the National Council. If there is only one candidate for this function, the elections will take the form of a referendum.

As President Federal can be chosen only one person holding voting rights in relation to the National Council and who is aged 35 years old on election day. There is also an exception, as members of royal houses or former royal families are not eligible for this function.

The mandate of the Federal President is six years and re-election to this office for a consecutive term is permitted only once.

During his term of office, the Federal President may not be a member of any general representative body nor perform any other function.

\footnotetext{
${ }^{4}$ See: I. Guceac, op. cit., p. 53; C. Călinoiu, V. Duculescu, G. Duculescu, op. cit., p. 313; S.G. Barbu, Constitution of the Republic of Austria. General presentation, in CONSTITUTIONAL CODEX. Constitutions of the Member States of the European Union. Ist Vol., Ș. Deaconu (coord.), I. Muraru, E.S. Tănăsescu, S.G. Barbu, A.D. Official Journal, Bucharest, 2015, p. 13, available on the web page http://codex.just.ro/Tari/Download/EU.
} 
The Federal President acts as the representative of Austria internationally, receives and accredits ambassadors, approves the appointment of consuls, appoints the consular representatives of the Republic abroad and concludes state treaties.

In accordance with the provisions of art. 65 par. 2 The Federal President also has the following powers:

a. appoints federal civil servants, including officers, as well as other federal officials, and awards them official titles;

b. establishes and grants professional titles;

c. for individual cases: the pardoning of those lawfully sentenced by courts, the reduction and altering of sentences pronounced by the courts, the remission of legal consequences and the annulment of sentences as acts of mercy, furthermore the quashing of criminal proceedings in regard to punishable actions committed in official capacity;

d. the declaration of illegitimate children as legitimate on the petition of parents.

\section{Legislative power}

\section{III.1. Legislation of the Federation - the National Council and the Federal Council}

The legislative power of the Federation is exercised, according to art. 24 of the Constitution by the National Council together with the Federal Council.

The National Council (Nationalrat) is elected for a five-year mandate according to the principle of proportional representation based on the equal, direct, personal, free and secret vote of men and women who, at the time of the election, are 16 years old. The Federal President convenes an annual regular session of the National Council, which will not start before September 15 and will not exceed 15 July of the following year art. 28 par. 1).

In the Federal Council (Bunderstat) the Länder are represented in proportion to the number of citizens in each Land, the number of members to be delegated by each Land being established, after each General Census, by the Federal President. Article 35 of the Constitution establishes that members of the Federal Council and their alternates are elected by the Länder legislatures for the duration of their legislative mandates in accordance with the principle of proportional representation, at least one seat (Mandat) must fall to the party which has the second highest number of seats in the Landtag, or, if several parties have the same number of seats, the one with the second highest number of electoral votes in the last Land Legislature election. In the event of equal claims by several parties a decision will be made by lot. Upon the expiration of the legislative period of a Land Legislature, or after its dissolution, the members who have been sent by it to the Federal Council continue to exercise their function, until the new Land Legislature has undertaken the election to the Federal Council. 
In the chairmanship of the Federal Council, the Länder alternate semiannually in alphabetical order.

The National Council and the Federal Council form the Federal Assembly and are convened by the Federal President.

Legislative proposals come to the National Council either as proposals by its members by the Federal Council or by one-third of the members of the Federal Council as well as bills of the Federal Government.

National Council exercises legislative power together with the Federal Council or a third of its members and the federal government in the form of bills. Constitutional laws or constitutional provisions contained in simple laws can be passed by the National Council only in the presence of at least one-half of the members and with a majority of two-thirds of the votes cast ${ }^{5}$.

The National Council may adopt a censure motion, in the presence of at least half of its members, against the Federal Government or its individual members, resulting in the revocation of the Federal Government or its individual members.

\section{III.2. Legislative power of the Landers}

The legislation of the Länder is exercised by the Land legislatures (Landtage). Their members are elected on the basis of equal, direct, secret and personal proportional representation suffrage of all male and female Land citizens in accordance with the Land electoral laws. By means of Land law more detailed provisions are made concerning obligatory voting (art. 95).

A Land law requires the adoption by the Land legislature, the authentication and countersignature in accordance with the provisions of the Land constitution and the promulgation by the Land Governor (Landeshauptmann) in the Land Law Gazette.

Insofar as a Land law foresees in its implementation the participation of Federal organs, the consent thereto of the Federal Government must be obtained. The consent is deemed to have been given if, within eight days from the day on which the legal enactment (Gesetzesbeschluss) arrived at the office of the Federal Chancellor, the Federal Government did not inform the Land Governor that the participation of the Federal organ is refused. Before the expiration of this deadline promulgation of the legal enactment may take place only if the Federal Government has expressly consented.

\section{Executive Power - Federal Government}

The Federal Government is composed of the Federal Chancellor, the Vice Chancellor, and the other federal ministers holding the supreme administrative duties in relation to the Federation, in so far as they do not belong to the Federal President. The Federal Government is coordinated by the Federal Chancellor.

${ }^{5}$ C. Călinoiu, V. Duculescu, G. Duculescu, op. cit., p. 315.

CONSTITUTIONAL LAW REVIEW 
The Federal Chancellor and, on his recommendation, the other members of the Federal Government are appointed by the Federal President. The revocation of individual members of the Federal Government takes place following the recommendation of the Federal Chancellor.

The Federal Chancellor is entrusted with the direction of the office of the Federal Chancellery, a Federal Minister is entrusted with the direction of each of the other Federal Ministries. The Federal President can entrust the technical direction (sachliche Leitung) of the particular matters which fall within the operational scope of the office of the Federal Chancellery, including the tasks personnel administration and organization to particular Federal Ministers, notwithstanding the continuation of the competence of the Federal Office of the Chancellery; such Federal Ministers have, with respect to these matters, the status of a competent Federal Minister [art. 77 alin. (3)].

Executive power in each land is exercised by a government of that land chosen by the Land.

\section{Judicial power}

In accordance with art. 82 of the Constitution, justice is carried out on the basis of jurisdictions and by the courts regulated by law at Federation level and the judgments and decisions of the courts are pronounced and enforced on behalf of the Republic.

The organization (Verfassung) and competence of the courts is established by Federal Law.

In relation to the exercise of the judicial power, it is expressly stated that no person can be deprived of justice before the competent court.

The appointment of judges is based on the proposal of the Federal Government, by the Federal President or, after authorization by the latter, by the Federal Minister responsible; The Federal Government or the Federal Minister will receive nomination proposals from the Chambers competent under the law of the organization of the courts. Provided that a sufficient number of candidates is available, the nomination that is to be submitted to the competent Federal Minister and transmitted by him to the Federal Government will include the names of at least three persons; however, if there are several vacancies, at least twice as many persons as there are judges are to be appointed (art. 86).

Public prosecutors are officials who carry out investigations and prosecutions in cases concerning the commission of some facts provided by the criminal law that falls within the jurisdiction of the courts.

Article 91 establishes the possibility for citizens to participate in the conduct of judicial proceedings and, in this respect, a jury will give a verdict on the defendant's guilt 
in the offenses for which the law provides for severe punishments to be specified by law, and also in all cases of political offenses. In criminal proceedings in connection with other offenses punishable under the law, consultant judges participate in the act of carrying out justice if the punishment to be applied exceeds a limit set by law.

\section{Constitutional control}

The Constitutional Court rules on pecuniary actions against the Federation, Länder, municipalities and municipal associations, which can not be settled through ordinary court proceedings or by a decision of an administrative authority.

The Austrian Constitutional Court rules on conflicts of jurisdiction between any court and administrative authorities; between the ordinary courts and the administrative courts of the Land or the Federal Administrative Court between the Constitutional Court and all other courts as well as between the Federation and a Land or between the Länder.

The Constitutional Court also decides whether a particular legislative or executive act falls within the sphere of competence of the Federation or the Länder, at the request of the Federal Government or the Government of a Land.

The court decides on the illegality of the orders at the request of a court; of its own motion, in so far as the Court will have to enforce the order in a process underway pending before it; at the request of a person claiming that his/her rights have been directly harmed by the unlawfulness of the act, whether the ordinance has entered into force in the absence of a judicial decision or whether a sentence has been pronounced which has had its effects on that person; at the request of a person deemed to be injured in his rights by a matter of law settled by a court on the merits by application of the provisions of the disputed order, an application made in the appeal against that judgment; of a federal authority at the request of the government of a Land or the People's Advocate; at the request of the authorities of a land at the request of the federal government or the People's Advocate, to the extent that the constitutional law of a land has declared the People's Advocate to be competent in the territorial sphere of the administration of that land; at the request of a supervisory authority as well as at the request of a locality whose ordinance has been canceled (art. 139).

The Constitutional Court carries out the constitutional control:

- the laws at the request of a court; of its own motion, to the extent that it will have to enforce such a law in a pending trial; at the request of a person who is deemed to be directly injured in his or her rights of violation of the Constitution, whether the law has entered into force in the absence of a judicial decision or whether a judgment which has 
been passed has begun to produce its effects for that person; at the request of a person deemed to be injured as a party to his/her rights by a decision of any court of first instance by application of an unconstitutional law by appeal against the decision;

- of the federal laws, at the request of a District Government, one-third of the members of the National Council or one third of the members of the Federal Council;

- the laws of a land at the request of the Federal Government or, if the constitutional law of a land permits, at the request of one-third of the members of the Länder.

On the cancellation of a law as unconstitutional, the Constitutional Court has this possibility only to the extent that its cancellation was specifically required or if the Court should apply the law in a pending trial. If, however, the Court decides that the law has been issued by an unqualified legislative authority from the competence point of view or has been published in an unconstitutional manner, it will annul the entire law as unconstitutional. This does not apply if the annulment of the law is contrary to the legitimate interests of the applicant who submitted the application or of which trial was subject to the ex officio initiation of the examination of the judicial procedure.

The Constitutional Court also has other prerogatives, such as: verifying the constitutionality and legality of international treaties, finding violations of international law under the provisions of a special federal law, ruling on judicial actions having as their object the constitutional responsibility of supreme authorities at federal and land level for violating the law in the exercise of their functions.

\section{The Office of the People's Attorney}

Chapter VIII of the Constitution regulates the People's Advocate Institution competent to resolve complaints against alleged maladministration by the Federation, including in its work as a holder of private rights, mainly for the alleged violation of human rights, provided that they are affected by a such mismanagement and in so far as they are not the subject of an appeal or are no longer open to further challenge.

The Ombudsman has the possibility to act ex officio in investigating any suspicious administration misconduct by the Federation, including the Federation's activity as a holder of private rights, in particular violations of human rights.

For the protection and promotion of human rights, the People's Advocate has the right to visit and inspect the places where the custodial measures are being executed; to verify, in an advisory capacity, the conduct of the activities of bodies authorized to exercise direct administrative and coercive powers and to check and visit some specialized institutions and programs for persons with disabilities. 


\section{Fundamental rights}

The Austrian constitution did not devote a separate chapter in which to structure in a structured way a catalog of fundamental rights and freedoms. However, most of the safeguards laid down in the European Convention on Human Rights can be found in the Austrian fundamental law Articles.

Thus, they find their regulation directly or indirectly: the right to life (Article 85 prohibits the death penalty), the right to petition, the right to education (art. 14 - „The fundamental values of education are democracy, humanity, solidarity, peace and justice, as well as honesty and tolerance towards people, which ensures to the whole population, independent of their origin, social and financial situation, a maximum educational level and permanently protects and develops optimum quality") the right to work and its guarantees, the right to vote and to be elected [art. 13 (3) - „In Austria, all persons entitled to vote in favor of the European Parliament and who, at the time of the election, are 18 years old, have the right to be elected"], the right to participate in representative bodies, the right to asylum, individual freedom and the like. Guarantee of equal treatment between men and women [art. 7 (1) - "The federation, the Länder and the localities adhere to the principle of equality between men and women. Measures to promote equality between women and men are allowed, in particular by eliminating existing inequalities"] as well as the protection of vulnerable persons find their regulation in the Constitution [art. 7 (1) - „The Republic, Federation, Länder and Municipalities are committed to guarantee equal treatment to the impaired and non-impaired humans in all areas of daily life" $]^{6}$.

The federal constitutional law on the protection of individual freedom comprises the main rights guaranteed by the Constitution and represents, together with the fundamental law, a constitutional document ${ }^{7}$.

\section{The relationship between the State and the European Union}

Austria joined the European Union in 1995 and, in this respect, amended the Constitution to regulate the relations between the state and the institutions of the European Union ${ }^{8}$.

Compliance with the principle of subsidiarity is ensured by the National Council and the Federal Council, which are called upon to lodge complaints against a legal act within the European Union at the Court of Justice of the European Union for breach of the principle of subsidiarity, in accordance with art. $23 \mathrm{~h}$ of the Constitution.

\footnotetext{
${ }^{6}$ S.G. Barbu, op. cit., p. 17.

${ }^{7}$ C. Călinoiu, V. Duculescu, G. Duculescu, op. cit., p. 313.

${ }^{8}$ Ş. Deaconu, The necessity of a constitutional change and the risks of the current proposal to revise the Constitution, in Law Magazine nr. 8/2014, pp. 171-180.
} 
The Austrian participation in the nomination of members of the Commission, the Court of Justice, the Court of First Instance, the Court of Accounts, the Administrative Council (Verwaltungsrat), or the European Investment Bank, the Economic and Social Committee, as well as the Committee of the Regions within the framework of the European Union is incumbent upon the Federal Government (art. 23c).

Article $23 f(1)$ states that the exercise of the powers provided for in the Treaty on European Union in the Treaty on the Functioning of the European Union and the protocols thereto as transposed by national parliaments into national law will be exercised by the National Council and the Council Federal.

\section{Conclusions}

In the context of Austria's membership of the European Union, analyzing the fundamental law is a necessary step for a better understanding of the constitutional systems of the Member States, so very necessary in a space dominated by the free movement.

The revision of the Austrian Constitution upon joining the European Union has been instrumental in establishing unequivocally the role of national institutions in European mechanisms, avoiding institutional blockages.

However, the regulation of human rights in a separate chapter of the fundamental law would be desirable in the context in which, in the absence of a catalog of fundamental rights and freedoms within the Constitution, it is necessary to identify them by going through the entire constitutional text and referring to the Federal Law relative to the protection of individual freedom. 